\title{
Performance and water usage of selected vegetables grown with different irrigation systems under house-type structures
}

\author{
Jessie C. Rom' ', Zenaida C. Gonzaga ${ }^{1 *}$, Othello B. Capuno' ${ }^{1}$, Ana Linda G. \\ Gorme', Warren L. Obeda', Sandra McDougall', Adam D. Goldwater ${ }^{3}$ and Gordon \\ S. Rogers ${ }^{3}$
}

\begin{abstract}
Irrigation for vegetables grown under protected cropping is very important for optimum production. Likewise, choosing an efficient method of irrigation can save water and labour. These studies were conducted to evaluate the effects of manual sprinkler, drip bottle, and drip hose method of water delivery systems on performance of selected vegetables, water use efficiency and profitability grown in house-type protective structures. The three crops tested were tomato, sweet pepper and ampalaya which were planted in similar structures arranged in randomized complete block design with three replications. The drip bottle method increased yield, irrigation water use efficiency, and profitability compared to sprinkler and drip hose method. Drip hose method effectively suppressed fusarium wilt. This implies that increasing productivity of some vegetables requires water delivery systems that provide a constant and even supply using a small amount of water. Further work is required in scheduling and rate of application with the drip hose method for it to become as efficient as the drip bottle.
\end{abstract}

Keywords: Income, evapotranspiration, UV treated, solanaceous, cucurbit, recycled bottles

\section{INTRODUCTION}

One of the considerations in vegetable production is efficient use of irrigation water to optimize production and use of water supplies. In areas with an abundant supply of water like in Leyte, Philippines, many farmers would not wisely use this resource as it is cheap or free. Over watering can be detrimental to plant growth, by triggering diseases, leaching of fertilizers, inhibiting certain physiological activities in the plant and increases production cost. Therefore, efficient use and good

\footnotetext{
'Visayas State University (VSU), Philippines

${ }^{2}$ Department of Primary Industries (DPI), Australia

${ }^{3}$ Applied Horticultural Research (AHR), Australia
* Corresponding Author. Address: Department of Horticulture, Visayas State University, Visca, Baybay City, Leyte,6521-A Philippines; Email:zcgonzaga@yahoo.com DOI: $10.32945 /$ atr39sb13.2017


management of water for irrigation is necessary to address problems including environmental impact of improper irrigation practice (Maughan et al 2015 \& Thompson et al 2007).

There are many irrigation systems used by farmers in the locality of Leyte, including manual sprinkler, drip bottle, drip hose, furrow and flooding methods. Today, the use of furrow and flooding are widely discouraged for use on vegetables due to the high incidence of bacterial contamination in low quality water sources (Bradford et al 2003). Microbial contamination is strictly prohibited in Philippine Good Agricultural Practice (PhilGAP) certification. Fertilizer leaching and contamination of pesticides were also some of the issues in these irrigation methods. Other methods of irrigation can be used to help minimize microbial contamination of fresh vegetables. However, there is limited information regarding the best water delivery systems for increased water use efficiency. Local farmers are unlikely to change their irrigation practices without local trials demonstrating their benefits.

Protected cropping requires an irrigation system due to the impermeable plastic roofing blocking rain (Capuno et al 2015). The water delivery system commonly used in this cultivation was drip hose. Problems occurred using this system such as low adoption by farmers due to financial limitations and accumulation of soil borne pathogens. Furthermore, there is a lack of work comparing different water delivery systems, in terms of which has better water use efficiency under protected cultivation. Therefore, these studies were conducted to determine the effect of water delivery systems on the performance of selected high value vegetables, water use efficiency and profitability under protected cultivation.

\section{MATERIALS AND METHODS}

\section{Site Description}

The studies were conducted in the Australian Centre for International Agricultural Research-Integrated Crop Management (ACIAR-ICM) project site of the Department of Horticulture, Visayas State University (VSU), Visca, Baybay City, Leyte on 2017. The site was located at $10^{\circ} 44^{\prime} 45.6^{\prime \prime} \mathrm{N} 124^{\circ} 47^{\prime} 30.7^{\prime \prime} \mathrm{E}$ and has $10 \mathrm{~m}$ elevation above sea level.

\section{Protective Structure}

The bamboo house-type structure of ACIAR-ICM project with curved roofing was used in the study. This protective structure measures $5 \mathrm{~m}$ wide, $40 \mathrm{~m}$ long, and stands $4 \mathrm{~m}$ high. The frame of the structure was made of bamboo poles and slats, with a UV-treated plastic roof.

\section{Experimental Design and Treatments}

Each experiment was arranged in Randomized Complete Block Design (RCBD) with three replications. The irrigation treatments were as follows:

$$
\begin{aligned}
& \text { T1-Manual sprinkler } \\
& \text { T2-Drip bottle } \\
& \text { T3-Drip hose }
\end{aligned}
$$


Performance and water usage of selected vegetables

The irrigation period was determined by Procheck moisture device with EC5 sensor. The basis of the irrigation was to maintain $30 \%$ field capacity of the soil every morning, with addition of water according to condition of the soil. Each plant received either $250 \mathrm{~mL}, 500 \mathrm{~mL}, 750 \mathrm{~mL}, 1000 \mathrm{~mL}$ or $1250 \mathrm{~mL}$ depending on the degree of saturation as determined by sensors.

Sprinkler method ( $\mathrm{T} 1$ ) used a plastic sprinkler ( 2 gal. capacity) which is used to manually sprinkle water into the plant base. The worker fetched water (similar source as the other treatments) and manually sprinkled the plant base like many farmers in the locality do. The volume of the water applied was recorded.

The drip bottle method (T2) used empty 1.5L plastic bottles (soft-drink containers). The recycled bottle was cut at the bottom for easy refill of water and a $2 \mathrm{~mm}$ diameter hole was made in the cap for a drip outlet. The bottle was placed upside down and fastened to a bamboo slat (Figure 1). The whole cap was buried in the soil to slow down the dripping of water into the surrounding soil. The water applied per day, per plot was recorded to determine the water use efficiency.

Drip hose method (T3 used Aqura J-turbo slim drip lines with $30 \mathrm{~cm}$ separating each emitter for ampalaya, and $25 \mathrm{~cm}$ for sweet pepper and tomato. This system dispensed 1.2L per hour as regulated by the emitter design. There was one drip line for ampalaya and two lines for tomato and sweet pepper, parallel to the bed, with emitters next to the base of the plant. A valve gate was left opened until the required amount of water had been applied. The total volume of water applied per replication plot was determined through the water meter installed in the system.

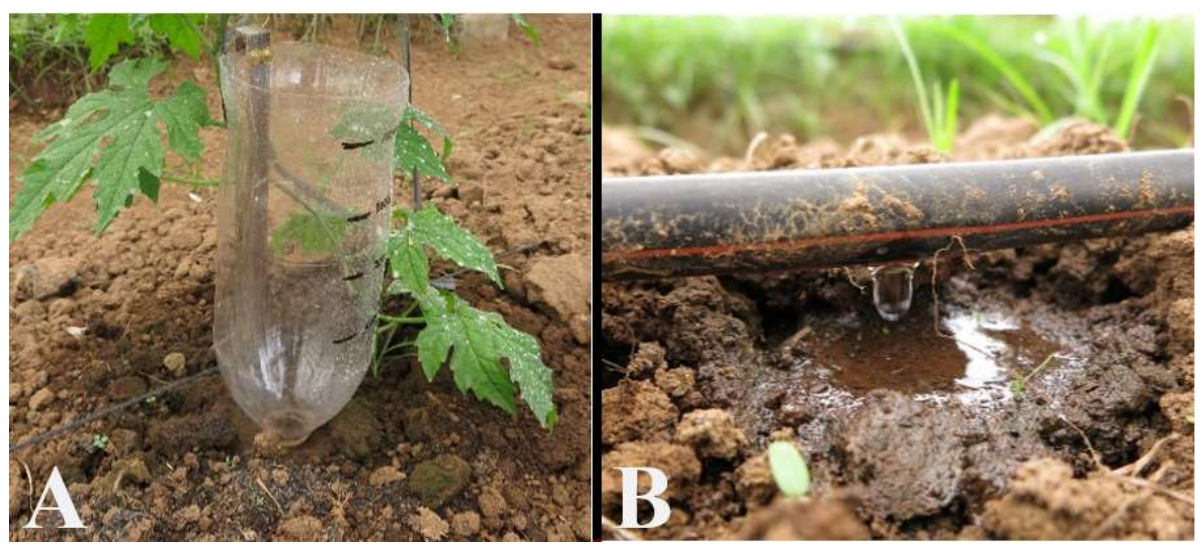

Figure 1. Drip bottle irrigation system (A) moistened the soil without creating surface water compared using drip hose (B) with fast drip

\section{Irrigation Water Use Efficiency}

Irrigation Water Use Efficiency (IWUE) was calculated using the ratio of total yield ( $t$ $\mathrm{ha}^{-1}$ ) and total volume of water ( $\mathrm{m}^{3}$ per ha) applied (Kang et al 2000). The formula is shown below:

IWUE $=\mathrm{Y} / \mathrm{I}$ 
Gonzaga et al

Where:

$$
\begin{aligned}
& \mathrm{Y}-\text { Total crop yield }\left(\mathrm{t} \mathrm{ha} \mathrm{C}^{-1}\right) \\
& \mathrm{I}-\text { Total volume of water applied ( } \mathrm{m}^{3} \text { per ha) }
\end{aligned}
$$

\section{Cultural Management}

The land preparation included plowing and harrowing twice. Soil samples were taken and submitted to laboratory located within the university for nutrient analysis. Tomato, sweet pepper and ampalaya were fertilized according to their recommended rates using vermicast, commercial complete fertilizer (16-1616 NPK) and calcium nitrate $(19 \% \mathrm{Ca} \& 15.5 \% \mathrm{~N})$. Plants were monitored for pest invasion and appropriate control measures were implemented. Crops were trained using trellising, with trellising net for ampalaya and ties to hold for tomato and sweet pepper. Weeding was done at weekly intervals within a month after transplanting. Harvesting was by hand and all crops were harvested every 2 days. Solanaceous crops were picked at breaker stage and ampalaya at immature-deep green appearance.

\section{Data Analysis}

The data gathered was analyzed by ANOVA using Statistical Tool for Agricultural Research (STAR) version 2.0.1 developed by International Rice Research Institute (IRRI) Biometrics group. Data from selected crops were pooled and means were compared by least significant difference (LSD) at $5 \%$ level of significance.

\section{RESULTS AND DISCUSSION}

\section{Plant Survival}

Survival of plants in the field was considered an important aspect of performance as it dictates the productivity of crop by affecting yield per unit area. Among the three crops tested, only sweet pepper survival was significantly affected by the water delivery system used (Table 1).

Sweet pepper was affected by fusarium wilt, which is increased by frequent wetting of the soil. This meant that highest plant survival was found using drip hose, followed by drip bottle and lastly the sprinkler method. In sprinkler, frequent wetting of the base (above soil surface) of sweet pepper enhanced the severity of the disease. Soil sticking to the stem caused by soil splashing during sprinkler irrigation was also noted. The disease was then enhanced as some microbes are carried in the soil. This disease was also the cause of most plant death in the drip bottle treatments due to maintained moisture in the soil, but in a very slight infection compared to the sprinkler irrigated plots. The drip hose method produced perfect $(100 \%)$ survival as disease infection was prevented, maybe due to alternate wetting and drying of soil that suppressed the pathogen. 
Performance and water usage of selected vegetables

Table 1. Survival (\%) at $2^{\text {nd }}$ month from transplanting and final plant height of selected vegetables as influenced by different water delivery systems planted in house-type protective structure of ACIARICM project, VSU, Visca, Baybay City, Leyte

\begin{tabular}{lcccccc}
\hline \multirow{2}{*}{$\begin{array}{l}\text { Water } \\
\text { delivery } \\
\text { system }\end{array}$} & Tomato & $\begin{array}{c}\text { Sweet } \\
\text { pepper }\end{array}$ & Ampalaya & Tomato & $\begin{array}{c}\text { Sweet } \\
\text { pepper }\end{array}$ & Ampalaya \\
\cline { 2 - 6 } & 98.61 & $73.33 \mathrm{c}$ & 100 & 126.07 & 98.71 & 481.21 \\
\hline Sprinkler & 100.00 & $96.67 \mathrm{~b}$ & 100 & 130.60 & 119.85 & 504.83 \\
Drip Bottle & 94.44 & $100.00 \mathrm{a}$ & 100 & 127.60 & 106.95 & 492.68 \\
Drip Hose & 9400 & & & & & \\
\end{tabular}

Means within the same column followed by a common letter and/or without letter designation are not significantly different from each other using least significant difference at $5 \%$ level of significance.

\section{Horticultural Characteristics}

The plant height and root parameters were presented in table 1 and 2 , respectively. There was no significant difference of final plant height of the three vegetables, and root parameters on sweet pepper and ampalaya with regards on irrigation system incorporated. However, significant difference was observed on root length and weight of tomato. Shorter length and lighter roots of sprinkler irrigated plants was likely due to insufficient water supply at times. There was fast evaporation, panning of soil surface and flooding away of water that resulted in wasted water using this method.

Table 2. Root length $(\mathrm{cm})$ and weight $(\mathrm{g})$ of the selected vegetables as influenced by different water delivery systems planted in house-type protective structure of ACIAR-ICM project, VSU, Visca, Baybay City, Leyte

\begin{tabular}{|c|c|c|c|c|c|c|}
\hline \multirow{3}{*}{$\begin{array}{l}\text { Water } \\
\text { delivery } \\
\text { system }\end{array}$} & \multicolumn{6}{|c|}{ Root parameters } \\
\hline & \multicolumn{3}{|c|}{ length (cm) } & \multicolumn{3}{|c|}{ fresh weight (g) } \\
\hline & Tomato & $\begin{array}{l}\text { Sweet } \\
\text { pepper }\end{array}$ & Ampalaya & Tomato & $\begin{array}{l}\text { Sweet } \\
\text { pepper }\end{array}$ & Ampalaya \\
\hline Sprinkler & $19.71 b$ & 27.61 & 36.19 & $16.74 b$ & 18.30 & 173.06 \\
\hline Drip Bottle & $28.60 a$ & 31.96 & 37.61 & $26.74 a$ & 22.85 & 188.83 \\
\hline Drip Hose & $26.70 a$ & 30.72 & 37.91 & $24.03 a$ & 22.67 & 160.22 \\
\hline
\end{tabular}

Means within the same column followed by a common letter and/or without letter designation are not significantly different from each other using least significant difference at $5 \%$ level of significance.

\section{Yield and Yield Components}

The number and weight of fruits of tomato and sweet pepper were significantly increased by drip bottle method of water delivery system than sprinkler and drip hose (Table 1). The insignificant result in ampalaya could be due to similar evaporation of the soil in all treatments as vines of the plant horizontally covered a large portion of the soil. However the use of drip bottles showed a consistent 
advantage over the other two methods on the solanaceous crops. The benefit from the drip bottle is likely due to the ability of drip irrigation technology to provide small and frequent water applications directly in the vicinity of the plant root zone (Lodhi et al 2014).

Although drip hose is a drip system, there was a difference in application times between the bottle drip and drip hose ie, the drip bottle was slower. The drip of water using the bottle was very slow as evident by several hours of drips before totally consumed compared to drip hose where given similar amount of water was consumed in just less than an hour. In other studies, plants grown with drip bottles absorbed more water and transpired more than using drip hose and sprinkling can. Increased transpiration in plants correlates with increased in yield (Bassil \& Kaffka 2002, Fernadez et al 2005 \& Pascale et al 2011). Drip hose likely applies excess water during the short application period, resulting in water that percolates deeper in the ground below the root system where it is unavailable to the plant.

Smaller and fewer sweet pepper fruit were obtained when using the sprinkler (Tables $3 \& 4$ ). This is likely that faster evaporation of water that remained on or near the soil surface causing insufficient water available to the plant. The sprinkler method applied more water on the soil surface which was then more prone to evaporation. Several applications with the sprinkler created soft panning of the soil surface that reduced absorption of surface water into the soil, leaving it to flood away from the base of the plant (Figure 2). Water is critical for plant growth, especially during flower and fruit development to prevent floral abortion and a lack of fruit growth. Hence the reduced yield and size of sweet pepper under sprinkler irrigation.

Table 3. Number and weight $\left(t \mathrm{ha}^{-1}\right)$ of fruits of the selected vegetables as influenced by different water delivery systems planted in house-type protective structure of ACIAR-ICM project, VSU, Visca, Baybay City, Leyte

\begin{tabular}{lcccccc}
\hline \multirow{2}{*}{$\begin{array}{l}\text { Water } \\
\text { delivery } \\
\text { system }\end{array}$} & \multicolumn{2}{c}{ No. of harvested fruits per plant } & \multicolumn{3}{c}{ Yield $\left(\mathrm{t} \mathrm{ha}^{-1}\right)$} \\
\cline { 2 - 6 } & Tomato & $\begin{array}{l}\text { Sweet } \\
\text { pepper }\end{array}$ & Ampalaya & Tomato & $\begin{array}{c}\text { Sweet } \\
\text { pepper }\end{array}$ & Ampalaya \\
\hline Sprinkler & $8.49 \mathrm{~b}$ & $35.24 \mathrm{~b}$ & 2.64 & $7.33 \mathrm{~b}$ & $15.15 \mathrm{c}$ & 15.14 \\
Drip Bottle & $12.63 \mathrm{a}$ & $55.95 \mathrm{a}$ & 2.85 & $13.80 \mathrm{a}$ & $28.09 \mathrm{a}$ & 18.43 \\
Drip Hose & $9.18 \mathrm{~b}$ & $42.43 \mathrm{~b}$ & 3.16 & $8.75 \mathrm{~b}$ & $21.69 \mathrm{~b}$ & 11.63 \\
\hline
\end{tabular}

Means within the same column followed by a common letter and/or without letter designation are not significantly different from each other using least significant difference at $5 \%$ level of significance. 
Performance and water usage of selected vegetables

Table 4. Fruit size $(\mathrm{cm})$ of selected vegetables as influenced by different water delivery systems planted in house-type protective structure of ACIAR-ICM project, VSU, Visca, Baybay City, Leyte

\begin{tabular}{lcccccc}
\hline \multirow{2}{*}{$\begin{array}{l}\text { Water } \\
\text { delivery } \\
\text { system }\end{array}$} & \multicolumn{5}{c}{ Polar diameter } & \multicolumn{5}{c}{ Equatorial diameter } \\
\cline { 2 - 7 } & Tomato $(\mathrm{cm})$ & $\begin{array}{c}\text { Sweet } \\
\text { pepper }\end{array}$ & Ampalaya & Tomato & $\begin{array}{c}\text { Sweet } \\
\text { pepper }\end{array}$ & Ampalaya \\
\cline { 2 - 7 } Sprinkler & $4.16 \mathrm{~b}$ & $8.05 \mathrm{~b}$ & 25.00 & $3.80 \mathrm{~b}$ & $3.02 \mathrm{~b}$ & 4.35 \\
Drip Bottle & $4.76 \mathrm{a}$ & $9.50 \mathrm{a}$ & 26.27 & $4.31 \mathrm{a}$ & $3.66 \mathrm{a}$ & 4.40 \\
Drip Hose & $4.55 \mathrm{a}$ & $10.07 \mathrm{a}$ & 25.11 & $4.11 \mathrm{a}$ & $3.67 \mathrm{a}$ & 4.38
\end{tabular}

Means within the same column followed by a common letter and/or without letter designation are not significantly different from each other using least significant difference at $5 \%$ level of significance.

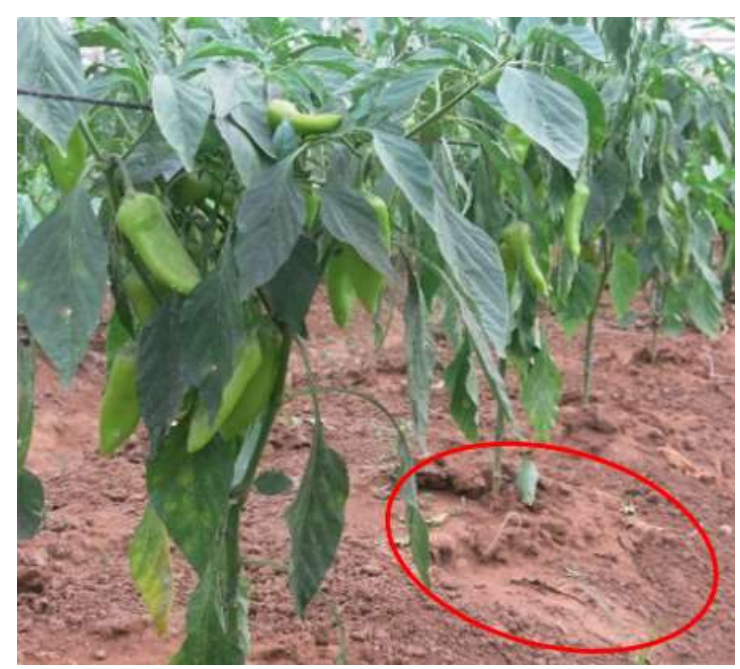

Figure 2. Soft panning of soil suface and mark of the flooding of water away from the base of the plant using manual sprinkler system which easily dried up

\section{Irrigation Water use Efficiency}

The water applied and IWUE clearly differed from three crops (tomato, sweet pepper \& ampalaya) which is attributed by differences in planting distance, duration and water absorption. (Table 5) The drip bottle method showed the lowest water application and highest efficiency except in ampalaya where there were no significant differences between the treatments. These similar results for ampalaya are likely due to the influence of the protective structure and climbing vines that covered a large portion of soil from sunlight, thus minimizing evaporation. 
Gonzaga et al

Table 5. Water applied ( $\mathrm{m}^{3}$ per ha) and irrigation water use efficiency $\left(\mathrm{t}\right.$ per $\mathrm{m}^{3}$ ) of selected vegetables as influenced by different water delivery systems planted in house-type protective structure of ACIAR-ICM project, VSU, Visca, Baybay City, Leyte

\begin{tabular}{|c|c|c|c|c|c|c|}
\hline \multirow{2}{*}{$\begin{array}{l}\text { Water } \\
\text { delivery } \\
\text { system }\end{array}$} & \multicolumn{3}{|c|}{$\begin{array}{l}\text { Water consumption } \\
\left(\mathrm{m}^{3} \text { per ha) }\right.\end{array}$} & \multicolumn{3}{|c|}{$\begin{array}{l}\text { Irrigation Water Use Efficiency } \\
\left(\mathrm{t} \text { per } \mathrm{m}^{3}\right)\end{array}$} \\
\hline & Tomato & $\begin{array}{l}\text { Sweet } \\
\text { pepper }\end{array}$ & Ampalaya & Tomato & $\begin{array}{l}\text { Sweet } \\
\text { pepper }\end{array}$ & Ampalaya \\
\hline Sprinkler & $204.75 a$ & $1111.85 a$ & 132.79 & $0.036 \mathrm{~b}$ & $0.014 \mathrm{c}$ & 0.114 \\
\hline Drip Bottle & $178.80 \mathrm{c}$ & $956.15 \mathrm{c}$ & 129.40 & $0.077 a$ & $0.029 a$ & 0.142 \\
\hline Drip Hose & $196.43 b$ & $1061.92 b$ & 172.22 & $0.045 b$ & $0.020 \mathrm{~b}$ & 0.068 \\
\hline
\end{tabular}

Means within the same column followed by a common letter and/or without letter designation are not significantly different from each other using least significant difference at $5 \%$ level of significance

Table 6. Estimates of the cost and return per hectare of selected vegetables with different water delivery systems planted in house-type protective structure of ACIAR-ICM project, VSU, Visca, Baybay City, Leyte

\begin{tabular}{|c|c|c|c|}
\hline \multirow{2}{*}{ Crop/Items } & \multicolumn{3}{|c|}{ Water delivery system } \\
\hline & Sprinkler & Drip Bottle & Drip Hose \\
\hline \multicolumn{4}{|l|}{ Tomato } \\
\hline A. Yield (kg per ha) & $7,330.00$ & $13,800.00$ & $8,750.00$ \\
\hline Price per kg* & 44.26 & 44.26 & 44.26 \\
\hline Revenue & $324,425.80$ & $610,788.00$ & $387,275.00$ \\
\hline \multicolumn{4}{|l|}{ B. Variable Cost } \\
\hline Materials & $172,909.50$ & $173,309.50$ & $184,909.50$ \\
\hline Labor & $122,000.00$ & $125,000.00$ & $95,000.00$ \\
\hline C. Net return $(A-B)$ & $29,516.30$ & $312,478.50$ & $107,365.50$ \\
\hline \multicolumn{4}{|l|}{ Sweet pepper } \\
\hline A. Yield (kg per ha) & $15,150.00$ & $28,090.00$ & $21,690.00$ \\
\hline Price per kg* & 55.29 & 55.29 & 55.29 \\
\hline Revenue & $837,643.50$ & $1,553,096.10$ & $1,199,240.10$ \\
\hline \multicolumn{4}{|l|}{ B. Variable Cost } \\
\hline Materials & $354,975.00$ & $358,725.00$ & $292,466.50$ \\
\hline Labor & $194,375.00$ & $194,375.00$ & $119,375.00$ \\
\hline C. Net return $(A-B)$ & $288,293.50$ & $999,996.10$ & $787,398.60$ \\
\hline
\end{tabular}


Performance and water usage of selected vegetables

Table 6 continued

\begin{tabular}{lrrr}
\hline \multirow{2}{*}{ Crop/ltems } & \multicolumn{3}{c}{ Water delivery system } \\
\cline { 2 - 4 } Ampalaya & Sprinkler & Drip Bottle & Drip Hose \\
A. Yield (kg per ha) & $15,140.00$ & $18,430.00$ & $11,630.00$ \\
Price per kg* & 64.77 & 64.77 & 64.77 \\
Revenue & $980,617.80$ & $1,193,711.10$ & $753,275.10$ \\
B. Variable Cost & & & \\
Materials & $203,296.50$ & $202,496.50$ & $215,296.50$ \\
Labor & $166,500.00$ & $166,500.00$ & $111,000.00$ \\
C. Net return (A-B) & $610,821.30$ & $824,714.60$ & $426,978.60$ \\
\hline
\end{tabular}

*Prices were based from the Bureau of Agricultural Statistics, data of Leyte, Philippines (2016) Note: Prices, costs, revenues and returns are expressed in Philippine peso

High IWUE on tomato and sweet pepper was attributed by high yield of plants (Table 4). The best performance of crops using the drip bottle was enhanced by the slow release of water. This was measured to be approximately $70-120 \mathrm{~mL}$ per hour. Frequent and gradual introduction of water to the root zone provided sufficient water to the plant for a whole day and minimized water application on the following day because the soil remained moist (Figure 1). This method minimized the water application and wastage in all three crops tested.

The inferior performance of drip hose and sprinkler was due to unavailability of water later in the day, since both were applied once early morning. In the drip hose method, application of water was for less than $1 \mathrm{~h}$, with a maximum of $1 \mathrm{~L}$ dripped, some of which possibly moved further than the plant root zone. Water was likely wasted through percolation deeper into the soil. On the other hand, some of the water using sprinkler were not available by the plants as soft panning of soil surface prevented better absorption.

These results suggest that the availability of water throughout the day, even in small quantities is important for better production of vegetables, particularly on solanaceous crops. The drip bottle method is a potential water delivery system for enhancing productivity of solanaceous crops in house-type protective structures. The drip hose method needs more improvement, especially with scheduling and the rate of application in order to be more efficient and as effective as the drip bottle.

\section{Cost and Return Analysis}

The most important part in crop production aside from producing quality crops is the ability to earn profit. From all crops tested, the use of the drip bottle consistently obtained the highest net return. These results were linked with the highest yield of fruits of the selected vegetables. Tomato production using sprinkler had the lowest return as a result of lower yield and higher costs due to labor inputs. There was almost a similar cost of labor for the sprinkler and drip bottle which were comparatively higher than drip hose due to the added activities of fetching of water and sprinkling/pouring water in to the plants. 
Gonzaga et al

\section{CONCLUSION}

The results presented suggest that drip bottles provide an effective and efficient water delivery system in house type-protective structures in Leyte. This method considerably increased yield and IWUE, minimized water application volume, and maximized profit on all three kinds of vegetables tested. The slow drip of water in this method provided constant supply of water to plants. Sprinklers had the highest water consumption as influenced by fast evaporation on the surface. Increased production costs of sprinkler and drip bottle was attributed to higher labor inputs. Future studies should be conducted to verify the results and determine the proper scheduling and rate of application when using drip hose irrigation. This may allow drip hose to be as effective as drip bottle, as it had the lowest cost of labor. This studies also find fusarium wilt incidence in sweet pepper correlated with increase in soil moisture and increased more when frequent wetting of stem.

\section{ACKNOWLEDGMENT}

The researchers would like to thank ACIAR for the research funds, to PCAARRD and to everyone who has contributed to this experiment.

\section{REFERENCES}

Bradford A, Brook R \& Hunshal CS. 2003. Wastewater Irrigation in Dubli-Dhar wad, India: Implications for Health and Livelihoods. Environment and Urbani zation 15(2):157-170. http://journals.sagepub.com/doi/pdf/10.1177/09562 4780301500206

Capuno OB, Gonzaga ZC, Loreto MB, Gerona RG, Borines LM, Tulin AB, Lusanta DC, Dimabuyu HB, Vega MLP, Mangmang JS \& Rogers GS. 2015. Development of a cost-effective protected vegetable cropping system in the Philip pines. Acta Horticulturae 1107:221-22. doi:10.17660/ActaHortic.2015.1107 .30

Bassil ES and Kaffka SR. 2002. Response of Safflower (Carthamus tinctorius L.) to Saline Soils and Irrigation: Consumptive Water Use. Agricultural Water Management 54(1):67-80

Fernandez MD, Gallardo M, Bochela S, Orgaz F \& Ferrer E. 2005. Water Use and Production of a Greenhouse pepper crop under optimum and limited water supply. The Journal of Horticultural Science and Biotechnology 80(1):87-96. doi:10.1080/14620316.2005.11511897

Kang SZ, Shi P, Pan YH, Liang ZS, Hu XT \& Zhang J. 2000. Soil water distribution, uniformity and water-use efficiency under alternate furrow irrigation in arid areas. Irrigation Science 19(4):181-190

Lodhi AS, Kaushal A \& Singh KG. 2014. Impact of Irrigation Regimes on Growth, Yield and Water Use Efficiency of Sweet Pepper. Indian Journal of Science and Technology 7(6):790-794

Maughan T, Frost D \& Allen LN. 2015. Vegetable Irrigation: Sweet pepper and Tomato. Horticulture/Vegetables/2015-03. www.extension.usu.edu. Retrieved on October 10, 2017

Thompson RB, Matibez-Gaitan C, Gallardo M, Gimenez C \& Fernandez MD. 2007. Identification of irrigation and $\mathrm{N}$ management practices that contribute to 
Performance and water usage of selected vegetables

nitrate leaching loss from an intensive vegetable production system by use of a comprehensive survey. Agricultural Water Management 89(2007):261-24. doi: 10.1016/j.agwat.2007.01.013

Pascale SD, Costa LD, Vallone S, Barbeiri G \& Maggio A. 2011. Increasing Water Use Efficiency in Vegetable Crop Production: From Plant to Irrigation Systems Efficiency. HortTechnology 21(3):301-308. Accessed in https://journals.ashs .org/horttech/view/journals/horttech/21/3/article-p301.pdf on October 10, 2017 